\title{
Lectotypification of $\times$ Anthepleurospermum gruetterianum (Asteraceae)
}

Artur Pliszko \& Waldemar Heise

Lectotypification of $\times$ Anthepleurospermum gruetterianum (Asteraceae). - Acta Mus. Siles. Sci. Natur. 65: 101-103, 2016.

Abstract: $\times$ Anthepleurospermum gruetterianum, a validly published name for the hybrid between Anthemis arvensis and Tripleurospermum inodorum, is lectotypified.

Key words: Anthemis arvensis, Tripleurospermum inodorum, hybrid, lectotype, plant taxonomy.

\section{Introduction}

$\times$ Anthepleurospermum gruetterianum (Asch.) Rothm. (Asteraceae) was proposed by Rothmaler (1963) as a new combination for the hybrid between Anthemis arvensis L. and Tripleurospermum inodorum (L.) Sch. Bip. The basionym refers to Anthe-Matricaria gruetteriana Asch. which was published by Ascherson (1891) as a condensed formula for the hybrid discovered and described by Grütter (1891). Since no type specimen is designated, we propose the specimen from the Herbarium of the Institute of Ecology and Environment Protection of the Nicolaus Copernicus University in Torun (TRN) as a lectotype. It was collected by Grütter in 1891 in Luszkówko, north-central Poland (formerly Luschkowko in the Province of West Prussia), one of the two localities cited by Ascherson (1891).

\section{Results and discussion}

$\times$ Anthepleurospermum gruetterianum (Asch.) Rothm., Exkursionsflora von Deutschland IV: 325. 1963. $\equiv$ Anthe-Matricaria gruetteriana Asch., Ber. Deutsch. Bot. Ges. 9: 99. 1891. $\equiv \times$ Tripleurothemis gruetteriana (Asch.) P.D. Sell in Sell \& Murrell, Fl. Gr. Brit. Ireland 4: 556. 2006. - Lectotype (here designated): Poland, Westpreussen, Kreis Schwetz, Luschkowko, 2 July 1891, M.E.H. Grütter s.n. (TRN!). Fig. 1.

$=\times$ Tripleurothemis inolens (P. Fourn.) Starm., Carinthia II 195/115(2): 524. 2005.

According to McKenzie (2001), ×Anthepleurospermum Rothm. is the earliest validly published condensed formula for the hybrids between Anthemis L. and Tripleurospermum Sch. Bip. Therefore, $\times$ Tripleurothemis Stace, a nothogeneric name proposed by Stace (1990), is superfluous and must be treated as a synonym. In consequence, two other combinations, i.e. $\times$ Tripleurothemis inolens (P. Fourn.) Starm. and $\times$ Tripleurothemis gruetteriana (Asch.) P.D. Sell (Starmühler 2005, Sell \& Murrell 2006), must be placed into synonymy of $\times$ Anthepleurospermum gruetterianum. Regarding the publication of $\times$ Tripleurothemis inolens, we found that Starmühler (2005) cited the incorrect date of publication of the basionym, namely ' 1828 ' instead of 1928 (Fournier 1928). It is also worth noting that Sell in the publication of $\times$ Tripleurothemis gruetteriana (Sell \& Murrell 2006) cited the basionym with an error using the nothogeneric name 'Anthemimatricaria' instead of Anthe-Matricaria.

Acknowledgement: The first author would like to thank Dr. Radosław Puchałka, the curator of the Herbarium of the Institute of Ecology and Environment Protection of the Nicolaus Copernicus University in Torun (TRN), for providing the access to Max Eugen Heinrich Grütter's collection. 


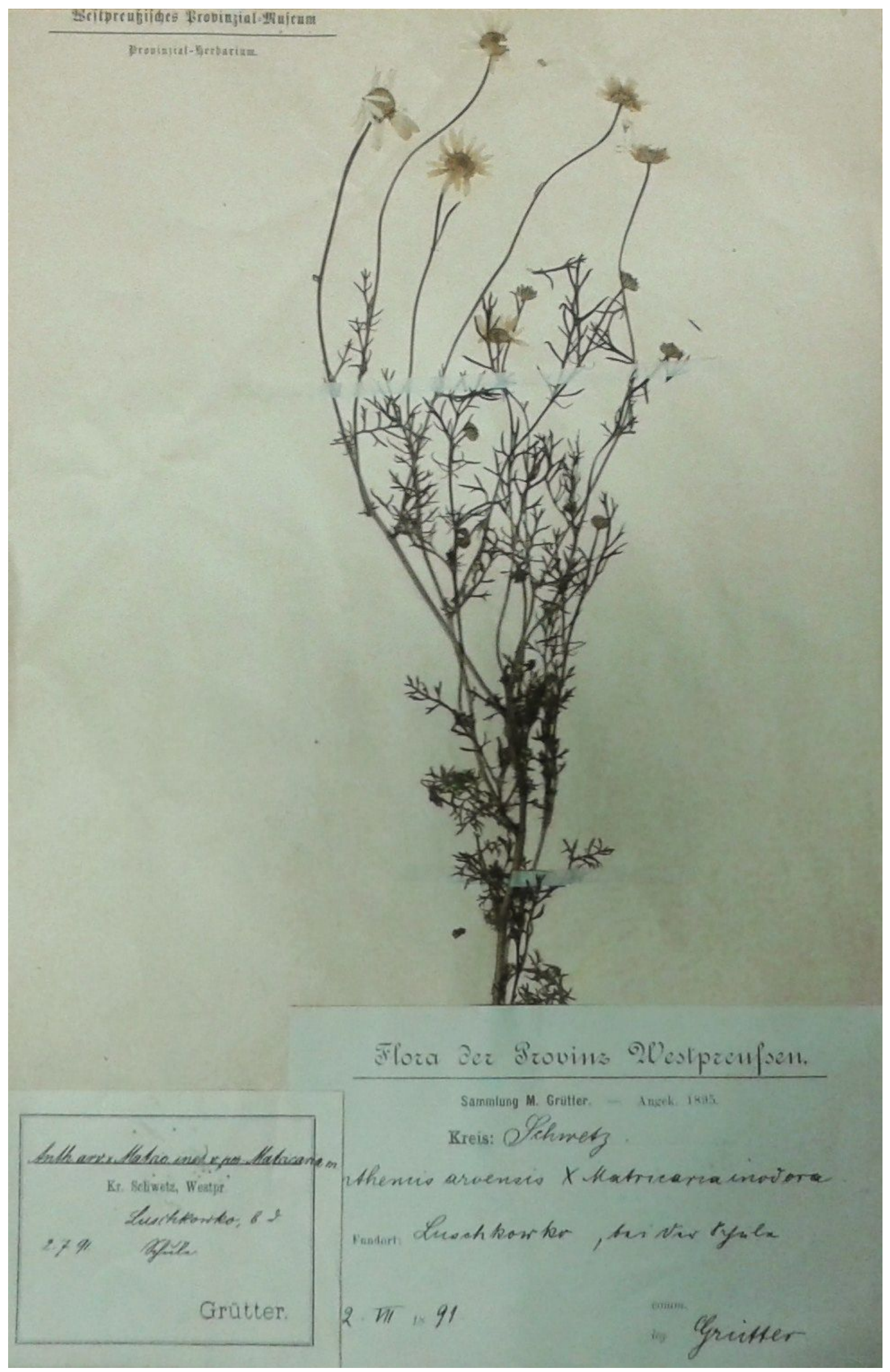

Fig 1: Lectotype of $\times$ Anthepleurospermum gruetterianum deposited in TRN. 


\section{References}

Ascherson P. (1891): Allgemeines. - Ber. Deutsch. Bot. Ges. 9: 95-102.

Fournier P.V. (1928): Flore complétive de la plaine française. Paul Lechavalier, Paris, 632 pp.

Grütter M.E.H. (1891): Anthemis arvensis $\times$ Matricaria inodora nov. hyb. - Deutsche Bot. Monatsschr. 9: 5-7.

McKenzie R.J. (2001): Intergeneric hybridisation in New Zealand Gnaphalieae (Compositae). PhD Thesis, University of Canterbury, New Zealand, 383 pp.

Rothmaler W. (1963): Exkursionsflora von Deutschland IV. Kritischer Ergänzungsband Gefässpflanzen. Volk und Wissen Volkseigener Verlag, Berlin, $622 \mathrm{pp}$.

Sell P.D. \& Murrell G. (2006): Flora of Great Britain and Ireland, vol. 4. Campanulaceae-Asteraceae. Cambridge University Press, Cambridge, $652 \mathrm{pp}$.

Stace C.A. (1990): New names and combinations in the British flora. - Watsonia 18: 212-213.

Starmühler W. (2005): Vorarbeiten zu einer "Flora von Istrien" Teil VIII. - Carinthia II 195/115(2): 515-654.

Authors' addresses: Artur Pliszko \& Waldemar Heise, Department of Plant Taxonomy, Phytogeography and Herbarium, Institute of Botany, Jagiellonian University in Kraków, Kopernika 31, 31-501 Kraków, Poland.

Corresponding author: artur.pliszko@uj.edu.pl 